\title{
Synthesis of 2a,8b-Dihydrocyclobuta[a]naphthalene- 3,4-diones
}

\author{
Kerstin Schmidt and Paul Margaretha*
}

\author{
Full Research Paper \\ Address: \\ Chemistry Department, University of Hamburg, Martin-Luther-King \\ Platz 6, D-20146 Hamburg, Germany \\ Email: \\ Paul Margaretha* - Paul.Margaretha@chemie.uni-hamburg.de \\ * Corresponding author \\ Keywords: \\ cyclobutenes; photocycloaddition; quinone monoacetals
}

\author{
Beilstein J. Org. Chem. 2010, 6, No. 76. doi:10.3762/bjoc.6.76 \\ Received: 07 May 2010 \\ Accepted: 02 July 2010 \\ Published: 13 July 2010 \\ Guest Editor: A. G. Griesbeck \\ (C) 2010 Schmidt and Margaretha; licensee Beilstein-Institut. \\ License and terms: see end of document.
}

Open Access

\begin{abstract}
On irradiation ( $\lambda=350 \mathrm{~nm}$ ) in neat hex-1-yne, naphthalene-1,2-dione monoacetals 1 afford mixtures of pentacyclic photodimers and up to $25 \%$ (isolated yield) of mixed photocycloadducts $\mathbf{2}$. Careful acidic hydrolysis of the acetal function of $\mathbf{2}$ gives the title compounds $\mathbf{3}$, the overall sequence representing a first approach to a (formal) [2+2] photocycloadduct of a 1,2-naphthoquinone to an alkyne.
\end{abstract}

\section{Introduction}

The behaviour of excited 1,2- and 1,4-quinones towards ground-state molecules differs greatly. Whereas the former typically react via $\mathrm{H}$-abstraction by an excited carbonyl group [1], the latter smoothly undergo [2 +2] cycloaddition to alkenes to afford cyclobutane-type products [2]. Very recently we reported the use of 1,2-dihydro-1,1-dimethoxynaphthalen-2ones 1 as protected precursors for the synthesis of both photocyclodimers and ketene-photocycloadducts of 1,2-naphtoquinones $[3,4]$. Here we report the preparation of - novel $2 \mathrm{a}, 8 \mathrm{~b}$-dihydrocyclobuta $[a]$ naphthalene-3,4-diones, i.e. (formal) 1,2-naphthoquinone + alkyne $[2+2]$ cycloadducts.

\section{Results}

Irradiation of $\mathbf{1}$ in the presence of alkynes affords the - known [3] - pentacyclic dimers and variable amounts $(0-33 \%)$ of enone + alkyne cycloadducts as indicated by ${ }^{1} \mathrm{H}$ NMR spectroscopy. The yields of mixed cycloadducts with many alkynes (3,3-dimethylbut-1-yne, trimethylsilylacetylene, 3-[(trimethylsilyl)oxy]prop-1-yne or hex-3-yne were invariably low $(<5 \%)$. Moderately higher yields (15-25\%) were obtained using hex-1yne in either benzene or acetonitrile as solvent. Best results were obtained using hex-1-yne, both as reaction partner and as solvent. Thus, irradiation of either $\mathbf{1 a}$ or $\mathbf{1 b}$ in neat hex-1-yne affords a mixture of the corresponding dimeric dibenzophenylenediones (two regioisomers [3], 67-70\%) and up to $30-33 \%$ of cycloadducts $\mathbf{2 a}$ or $\mathbf{2 b}$, respectively. Compounds $\mathbf{2}$ can easily be isolated by chromatography ( $25 \%$ isolated yield) as they exhibit much higher $R_{\mathrm{f}}$-values than the corresponding dimers. In contrast, naphthalenone $1 \mathrm{c}$ under the same conditions only affords $<5 \%$ of $\mathbf{2 c}$. Hydrolysis of cycloadducts $\mathbf{2}$ in a 
two phase mixture $\left(\mathrm{CH}_{2} \mathrm{Cl}_{2}\right.$, aq $\left.\mathrm{HCl}\right)$ at r.t. [5] leads to quantitative deprotection of the acetal function as indicated by ${ }^{1} \mathrm{H}$ NMR spectroscopy to afford compounds $\mathbf{3 a}$ or $\mathbf{3 b}$, respectively (Scheme 1). Compounds $\mathbf{3}$ are also easy to purify by chromatography ( $83-85 \%$ isolated yield) which is greatly assisted by the fact that they are easily detectable on account of their yellow colour.

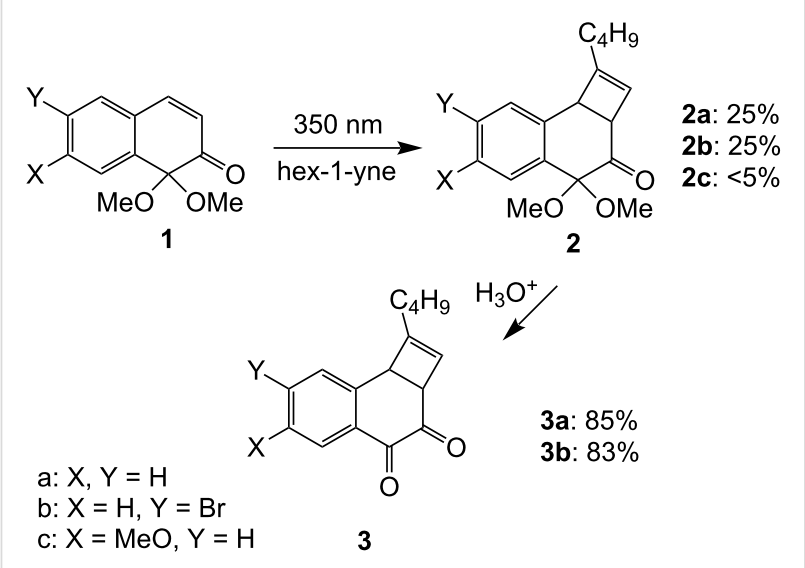

Scheme 1: Synthesis of 2a,8b-dihydrocyclobuta[a]naphthalene-3,4diones.

\section{Discussion}

At first glance, the (relatively) low yield of mixed cycloadduct formation from excited $\mathbf{1}$ and alkynes seems disappointing. Nevertheless, one should bear in mind that $a$ ) dimer formation on irradiation of phenyl-conjugated enones, e.g., 3-phenylcyclohex-2-enone, is not suppressed even in neat alkenes as solvent [6], as these compounds tend to associate via $\pi-\pi$-stacking, and b) radical additions to alkynes usually proceed with significantly lower relative rates $(30-50 \%)$ than those to the corresponding alkenes [7]. Taking these findings and the observed regioselectivity of the cycloaddition into consideration, the maximum relative yield (33\%) of compounds $\mathbf{2 a}$ or $\mathbf{2 b}$ at total conversion of starting material is acceptable. Moreover, the fact that hydrolysis of the cycloadducts proceeds quantitatively, then the overall yields in the preparation of the - novel - 1,2-naphthoquinone + alkyne cycloadducts even becomes satisfactory. In the same experiment with $\mathbf{1 c}$, the $\mathrm{MeO}$-group apparently tends to increase the efficiency in photodimerization vs mixed photocycloaddition, otherwise there is no obvious explanation for this result.

\section{Experimental}

1. General. Acetals 1 were synthesized according to [8]. Both 1b, m.p. $60-62{ }^{\circ} \mathrm{C}$, and 1c, m.p. $76-78{ }^{\circ} \mathrm{C}$, originally described as oils, solidified on standing. Hex-1-yne was commercially available. Photolyses were conducted in a Rayonet RPR-100 photoreactor equipped with (16) $350 \mathrm{~nm}$ lamps. Column chromatography (CC) was carried out with silica gel 60 (Merck; 230-400 mesh). ${ }^{1} \mathrm{H}$ and ${ }^{13} \mathrm{C}$ NMR spectra (including 2D plots) were recorded with a Bruker WM-500 instrument at 500.13 and 125.8 MHz, resp., in $\mathrm{CDCl}_{3}, \delta$ in ppm, $J$ in $\mathrm{Hz}$.

2. Photolyses. Ar-Degassed solns. of 1 ( $1 \mathrm{mmol})$ in hex-1-yne $(10 \mathrm{ml})$ were irradiated for $15 \mathrm{~h}$ up to total conversion (monitoring by TLC). After evaporation of the excess alkyne, the crude mixtures were analyzed by ${ }^{1} \mathrm{H}$ NMR in order to determine the crude yield. $\mathrm{CC}\left(\mathrm{SiO}_{2}\right.$, pentane/Et $\left.2 \mathrm{O} 6: 1\right)$ gave the photocycloadducts 2. 1-Butyl-3,4-dihydro-4,4-dimethoxy$2 a \mathrm{H}, 8 b \mathrm{H}$-cyclo-buta[a]naphthalen-3-one (2a): $72 \mathrm{mg}$ (25\%), colourless oil, $R_{\mathrm{f}}=0.65 .{ }^{1} \mathrm{H}$ NMR: $7.70(\mathrm{~d}, J=8.4,1 \mathrm{H}) ; 7.36(\mathrm{t}$, $J=8.4,1 \mathrm{H}) ; 7.30(\mathrm{~m}, 2 \mathrm{H}) ; 5.97(\mathrm{~s}, 1 \mathrm{H}) ; 4.52(\mathrm{~d}, J=4.6,1 \mathrm{H})$; $4.00(\mathrm{bs}, 1 \mathrm{H}) ; 3.53 \& 3.00(\mathrm{~s}, 3 \mathrm{H}) ; 2.16(\mathrm{t}, J=7.0,2 \mathrm{H}) ; 1.52$ $(\mathrm{m}, 2 \mathrm{H}) ; 1.38(\mathrm{~m}, 2 \mathrm{H}) ; 0.92(\mathrm{t}, J=6.9,3 \mathrm{H}) .{ }^{13} \mathrm{C}$ NMR: 203.1 (s); 156.2 (s); 137.3 (s); 134.5 (s); 129.1 (d); 128.6 (d); 128.4 (d); $127.8(\mathrm{~d}) ; 125.2(\mathrm{~d}) ; 99.1$ (s); 51.0 (q); 50.1 (d); 49.2 (q); $48.3(\mathrm{~d}) ; 30.2(\mathrm{t}) ; 28.6(\mathrm{t}) ; 22.5(\mathrm{t}) ; 14.2(\mathrm{q})$. Anal. Calcd for $\mathrm{C}_{18} \mathrm{H}_{22} \mathrm{O}_{3}$ : C, 75.50; H, 7.74. Found: C, 75.43; H, 7.78. 7-Bromo-1-butyl-3,4-dihydro-4,4-dimethoxy- $2 a \mathrm{H}, 8 b \mathrm{H}-c y c l o-$ buta[a]naphthalen-3-one (2b): $91 \mathrm{mg}$ (25\%), light yellow solid, m.p. $50-52{ }^{\circ} \mathrm{C}, R_{\mathrm{f}}=0.61 .{ }^{1} \mathrm{H}$ NMR: $7.55(\mathrm{~d}, J=8.4,1 \mathrm{H}) ; 7.42$ $(\mathrm{s}, 1 \mathrm{H}) ; 7.41(\mathrm{~d}, J=8.4,1 \mathrm{H}) ; 5.96(\mathrm{~s}, 1 \mathrm{H}) ; 4.46(\mathrm{~d}, J=4.6,1 \mathrm{H})$; 3.95 (bs, 1H); $3.52 \& 2.97$ (s, 3H); $2.16(\mathrm{t}, J=7.0,2 \mathrm{H}) ; 1.52$ $(\mathrm{m}, 2 \mathrm{H}) ; 1.38(\mathrm{~m}, 2 \mathrm{H}) ; 0.93(\mathrm{t}, J=6.9,3 \mathrm{H}) .{ }^{13} \mathrm{C}$ NMR: 203.2 (s); 156.2 (s); 135.9 (s); 135.5 (s); 133.0 (s); 131.9 (d); 129.9 (d); 129.8 (d); 125.8 (d); 99.1 (s); 51.1 (q); 50.2 (d); 49.1 (q); $48.2(\mathrm{~d}) ; 30.2(\mathrm{t}) ; 28.6(\mathrm{t}) ; 22.5(\mathrm{t}) ; 14.2(\mathrm{q})$. Anal. Calcd for $\mathrm{C}_{18} \mathrm{H}_{21} \mathrm{BrO}_{3}$ : C, 59.19; H 5.79. Found: C, 59.22; H, 5.82.

3. Hydrolyses. To a soln. of the acetal $2(0.2 \mathrm{mmol})$ in $\mathrm{CH}_{2} \mathrm{Cl}_{2}$ $(2 \mathrm{ml})$, was added $8 \mathrm{~N} \mathrm{HCl}(1.5 \mathrm{ml})$ and the mixture stirred for $5 \mathrm{~h}$ at room temperature. The org. phase was washed with sat. aq $\mathrm{NaCl}$, dried $\left(\mathrm{MgSO}_{4}\right)$ and the residue $(100 \%$ conversion to product from $\left.{ }^{1} \mathrm{H} \mathrm{NMR}\right)$ purified by $\mathrm{CC}\left(\mathrm{SiO}_{2}\right.$, pentane/Et ${ }_{2} \mathrm{O}$ 1:1) to afford the diketones 3. 1-Butyl-2a,8b-dihydrocyclobuta[a]naphthalene-3,4-dione (3a): $37 \mathrm{mg}$ (85\%), viscous yellow oil, $R_{\mathrm{f}}=0.45 .{ }^{1} \mathrm{H}$ NMR: $8.06(\mathrm{~d}, J=8.5,1 \mathrm{H}) ; 7.62(\mathrm{t}, J$ $=8.5,1 \mathrm{H}) ; 7.42(\mathrm{t}, J=8.5,1 \mathrm{H}) ; 7.37(\mathrm{~d}, J=8.5,1 \mathrm{H}) ; 5.72(\mathrm{~s}$, $1 \mathrm{H}) ; 4.25(\mathrm{~d}, J=3.2,1 \mathrm{H}) ; 4.16(\mathrm{bs}, 1 \mathrm{H}) ; 1.97(\mathrm{~m}, 2 \mathrm{H}) ; 1.40(\mathrm{~m}$, $2 \mathrm{H}) ; 1.26(\mathrm{~m}, 2 \mathrm{H}) ; 0.83(\mathrm{t}, J=6.9,3 \mathrm{H}) .{ }^{13} \mathrm{C} \mathrm{NMR:} 196.2(\mathrm{~s})$; 184.5 (s); 164.1 (s); 144.2 (s); 137.1 (s); 134.5 (d); 130.1 (d); 128.4 (d); 127.8 (d); 122.5 (d); 48.5 (d); 46.4 (d); 28.8 (t); 28.0 (t); 27.4 (t); 22.4 (q). Anal. Calcd for $\mathrm{C}_{16} \mathrm{H}_{16} \mathrm{O}_{2}: \mathrm{C}, 79.97 ; \mathrm{H}$, 6.71. Found: C, 79.92; H, 6.85. 7-Bromo-1-butyl-2a,8b-dihydrocyclobuta[a]naphthalene-3,4-dione (3b): $48 \mathrm{mg}$ (83\%), viscous yellow oil, $R_{\mathrm{f}}=0.41 .{ }^{1} \mathrm{H}$ NMR: $7.94(\mathrm{~d}, J=8.5,1 \mathrm{H})$; $7.58(\mathrm{~d}, J=8.5,1 \mathrm{H}) ; 7.53(\mathrm{~s}, 1 \mathrm{H}) ; 5.74(\mathrm{~s}, \mathrm{H}) ; 4.19(\mathrm{~d}, J=3.1$, $1 \mathrm{H}) ; 4.15$ (bs, $1 \mathrm{H}) ; 1.99(\mathrm{~m}, 2 \mathrm{H}) ; 1.40(\mathrm{~m}, 2 \mathrm{H}) ; 1.26(\mathrm{~m}, 2 \mathrm{H})$; 
$0.84(\mathrm{t}, J=6.9,3 \mathrm{H}) .{ }^{13} \mathrm{C}$ NMR: $196.1(\mathrm{~s}) ; 184.6(\mathrm{~s}) ; 164.2(\mathrm{~s})$; 144.2 (s); 137.1 (s); 134.5 (d); 130.1 (s); 128.4 (d); 127.8 (d); 122.5 (d); 48.6 (d); $46.3(\mathrm{~d}) ; 28.8(\mathrm{t}) ; 28.0(\mathrm{t}) ; 27.4(\mathrm{t}) ; 22.4(\mathrm{q})$. Anal. Calcd for $\mathrm{C}_{16} \mathrm{H}_{15} \mathrm{BrO}_{2}$ : C, 60.21; H, 4.71. Found: $\mathrm{C}$, $60.13 ; \mathrm{H}, 4.77$.

\section{References}

1. Oelgemoeller, M.; Mattay, J. The "Photochemical Friedel-Crafts Acylation" of Quinones: From the Beginnings of Organic Photochemistry to Modern Solar Chemical Applications. In Handbook of Organic Photochemistry and Photobiology, 2nd ed.; Horspool, W. M.; Lenzi, F., Eds.; CRC Press: Boca Raton, USA, 2004; 88-1.

2. Gilbert, A. 1,4-Quinone Cycloaddition Reactions with Alkenes, Alkynes, and Related Compounds. In Handbook of Organic Photochemistry and Photobiology, 2nd ed.; Horspool, W. M.; Lenzi, F., Eds.; CRC Press: Boca Raton, USA, 2004; 87-1

3. Schmidt, K.; Kopf, J.; Margaretha, P. Helv. Chim. Acta 2007, 90, 1667. doi:10.1002/hlca.200790172

4. Schmidt, K.; Margaretha, P. Helv. Chim. Acta 2008, 91, 1625. doi:10.1002/hlca.200890177

5. De Kimpe, N.; Verhé, R.; De Buyck, L.; Schamp, N. J. Org. Chem. 1978, 43, 2933. doi:10.1021/jo00408a047

6. McCullough, J. J.; Ramachandran, B. R.; Snyder, F. F.; Taylor, G. N. J. Am. Chem. Soc. 1975, 97, 6767. doi:10.1021/ja00856a028

7. Santi, R.; Bergamini, F.; Citterio, A.; Sebastiano, R.; Nicolini, M. J. Org. Chem. 1992, 57, 4250. doi:10.1021/jo00041a034

8. Mal, D.; Roy, H. N.; Hazra, N. K.; Adhikari, S. Tetrahedron 1997, 53, 2177. doi:10.1016/S0040-4020(96)01119-2

\section{License and Terms}

This is an Open Access article under the terms of the Creative Commons Attribution License (http://creativecommons.org/licenses/by/2.0), which permits unrestricted use, distribution, and reproduction in any medium, provided the original work is properly cited.

The license is subject to the Beilstein Journal of Organic Chemistry terms and conditions:

(http://www.beilstein-journals.org/bjoc)

The definitive version of this article is the electronic one which can be found at: doi:10.3762/bjoc. 6.76 